\title{
The effect of size and density on mean retention time of particles in the gastrointestinal tract of sheep
}

\author{
BY M. KASKE AND W. v. ENGELHARDT \\ Department of Physiology, School of Veterinary Medicine, Bischofsholer Damm 15, D-3000 \\ Hannover 1, Federal Republic of Germany
}

(Received 7 April 1989 - Accepted 24 November 1989)

\begin{abstract}
The selective retention of particles in the reticulo-rumen and in the gastrointestinal tract distal to the reticulo-rumen was studied in fistulated sheep maintained on a roughage diet. Polyethylene glycol and plastic particles of different lengths $(1$ and $10 \mathrm{~mm})$ and densities $(0.92,1.03,1.22$ and $1.44 \mathrm{~g} / \mathrm{ml})$ were either fed or were introduced into the omasum. The mean retention time in the reticulo-rumen (MRT $\mathbf{R R}_{\mathrm{RR}}$ ) of $1 \mathrm{~mm}$ long particles with a density of approximately $1.0 \mathrm{~g} / \mathrm{ml}$ was about $67 \mathrm{~h}$, that is eight times longer than the $\mathbf{M R T}_{\mathrm{RR}}$ of fluid; the heavier particles were retained only three times longer than fluid. Particles with a length of $10 \mathrm{~mm}$ were retained in the reticulo-rumen 19-28 h longer than $1 \mathrm{~mm}$ long particles of the same density. Particles with a length of $10 \mathrm{~mm}$ were reduced to smaller particles $(0.5-4 \mathrm{~mm})$ due to rumination. Multiple regression analysis indicated that particle density and particle size accounted for 59 and $28 \%$ of the total variation of $\mathrm{MRT}_{\mathrm{RR}}$ respectively. The mean retention time distal to the reticulorumen (MRT $T_{\text {Gut }}$ ) of 1 and $10 \mathrm{~mm}$ long particles with a density near $1.0 \mathrm{~g} / \mathrm{ml}$ was $18-19 \mathrm{~h}$, similar to that of fluid $(16 \mathrm{~h})$. The heavier particles were retained about $3-8 \mathrm{~h}$ longer.
\end{abstract}

Particle size and density: Mean retention time: Reticulo-rumen: Sheep

The microbial degradation of plant cell walls is a rather slow process. To achieve a high digestibility of cellulose, ruminants retain feed particles substantially longer than fluid in the reticulo-rumen. The mechanism by which the selective retention of particles is attained is not well understood.

From faecal analysis it has been calculated that feed particles longer than 1-2 $\mathrm{mm}$ have a very low probability of leaving the reticulo-rumen compared with small particles (Troelsen \& Campbell, 1968; Reid et al. 1977; Welch, 1982; Ulyatt, 1983). This sizedependent retention of particles in the rumen led to the 'critical size theory' (Poppi et al. 1980). This concept divides the rumen particles into two pools: a large-particle pool, which cannot pass out of the rumen, and a small-particle pool, which can leave the rumen (Martz \& Belyea, 1986). Less attention has been paid to the influence of particle density on mean retention time, although an effect was demonstrated in earlier studies (King \& Moore, 1957; Campling \& Freer, 1962). Recently, it was shown that particles with a density between 1.17 and $1.42 \mathrm{~g} / \mathrm{ml}$ leave the rumen of cows faster than particles with a higher or a lower density (Durkwa, 1983; desBordes \& Welch, 1984; Ehle, 1984; Ehle \& Stern, 1986).

The objective of the present study was to estimate the quantitative contribution of particle density and size to mean retention time in the reticulo-rumen $\left(\mathrm{MRT}_{\mathrm{RR}}\right)$ and in the gastrointestinal tract distal to the reticulo-rumen $\left(\mathrm{MRT}_{\mathrm{Gut}}\right)$ of sheep.

\section{MATERIALS AND METHODS \\ Plastic particles}

Plastic particles of different densities were manufactured by mixing polyethylene (PE; DSK 1812, HPPE, BASF, Ludwigshafen) with increasing proportions of barium sulphate (DAB 
6, Merck, Darmstadt) and a dye in a computerized kneader (Haake Buchler System 40, Haake, Karlsruhe, FRG) at a temperature of $150^{\circ}$. The mixtures were then extruded through a $0.7 \mathrm{~mm}$ nozzle, and the emerging filaments were rolled on metal frames $(100 \times 300 \mathrm{~mm})$. These frames were placed under a press, and filaments were cut with parallel steel knives to lengths of 1 and $10 \mathrm{~mm}$ respectively. Density of the particles was controlled using a precision balance with density set (Mettler AE 160, Mettler, Gießen); this allowed determination of density differences up to $0.001 \mathrm{~g} / \mathrm{ml}$. These plastic particles were similar in size and density to normal feed particles in the reticulo-rumen. The impact strength of the mixtures was measured during the production process by the determination of the torque. The values varied between mixtures of different densities by not more than $15 \%$. Therefore, particles of different densities were comminuted due to rumination to the same extent. Particles (1000) of each density and size were counted and weighed. Particles of length $10 \mathrm{~mm}$ of all densities were flexible. The physical properties of the particles are listed in Table 1.

\section{Experimental design}

Blackhead sheep (three wethers and one female) weighing between 60 and $75 \mathrm{~kg}$ were each fitted with a rumen fistula. Sheep had been adapted over several months to a diet of medium-quality hay (g/kg dry matter: crude fibre 360 (Weende analysis; Nehring, 1960), crude protein (nitrogen $\times 6.25$ ) 147 , ash 90 ), given ad lib. Water and mineralized salt licks were accessible at all times.

In the experimental periods the animals were kept in metabolism crates. They were fed three times each day $(08.00,13.00$ and 17.00 hours) on $800 \mathrm{~g}$ hay/meal. The feed refusal was weighed and removed before the next feed. The adaptation period before each experiment was at least $5 \mathrm{~d}$.

\section{The mean retention time (MRT) of fluid and of plastic particles in the total gastrointestinal tract $\left(M R T_{G i r}\right)$}

At 08.00 hours of the 1 st day 10000 plastic particles with a length of $1 \mathrm{~mm}$ of each density and 1000 particles with a length of $10 \mathrm{~mm}$ of each density, mixed with $150 \mathrm{~g}$ ground commercial dairy concentrate, were fed to each sheep. The sheep ate this mixture within $5 \mathrm{~min}$.

Rumen fluid volume and the MRT of fluid in the reticulo-rumen were estimated with polyethylene glycol (PEG; molecular weight 4000; Merck, Darmstadt). A single dose of $6 \mathrm{~g}$ $\mathrm{PEG}$ dissolved in $12 \mathrm{ml}$ water was administered through the fistula. Rumen samples were taken $2,4,6,8,10,12$ and $14 \mathrm{~h}$ after the injection. Samples were stored at $4^{\circ}$ and analysed nephelometrically at $90^{\circ}$ to the incident light according to Hydén (1955).

Total faecal output was collected on the 1 st day at intervals of $3 \mathrm{~h}$, on the 2 nd day at intervals of $6 \mathrm{~h}$ and twice daily for the following $8 \mathrm{~d}$. The faeces were dried at $105^{\circ}$ for $24 \mathrm{~h}$ for determination of dry matter. The faeces of each collection period were divided into three equal subsamples; one subsample $(33 \%)$ of each period was ground in a coffee grinder (K 6; Bosch, Stuttgart) for $45 \mathrm{~s}$. Preliminary studies had indicated that this method did not change the size of the plastic particles. Ground subsamples were sieved through a $500 \mu \mathrm{m}$ wire-mesh sieve (Retsch, Haan). The plastic particles on the sieve were manually separated from the remaining faecal particles, and sorted according to their density by colour. Subsamples containing larger amounts of plastic particles were separated by density gradients. Salt solutions of increasing density were used to separate the plastic particles by sedimentation and flotation (Hooper et al. 1984). Plastic particles of each density were dried and weighed. The concentration of the marker was determined by calculation as $g$ particles per $g$ faecal dry matter for each density and each initial particle size. 
Table 1. Composition and properties of plastic particles

\begin{tabular}{cclccccc}
$\begin{array}{l}\text { Density } \\
(\mathrm{g} / \mathrm{ml})\end{array}$ & $\begin{array}{c}\text { Length } \\
(\mathrm{mm})\end{array}$ & Colour & $\begin{array}{c}\text { Diameter } \\
(\mathrm{mm})\end{array}$ & $\begin{array}{c}\text { Weight } \\
(\mathrm{g} / 1000)\end{array}$ & $\begin{array}{c}\text { PE } \\
(\mathrm{g} / \mathrm{kg})\end{array}$ & $\begin{array}{c}\text { Barium } \\
\text { sulphate } \\
(\mathrm{g} / \mathrm{kg})\end{array}$ & $\begin{array}{c}\text { Dye } \\
(\mathrm{g} / \mathrm{kg})\end{array}$ \\
\hline 0.919 & 1.05 & Red & 0.798 & 0.4785 & 970 & 0 & 30 \\
0.917 & 10.0 & Grey & 0.841 & 5.2210 & 970 & 0 & 30 \\
1.025 & 1.05 & Yellow & 0.802 & 0.5577 & 845 & 125 & 30 \\
1.028 & 10.0 & Magenta & 0.813 & 5.5880 & 845 & 125 & 30 \\
1.216 & 1.05 & Orange & 0.760 & 0.6152 & 660 & 310 & 30 \\
1.219 & 10.0 & Dark Red & 0.750 & 5.6767 & 660 & 310 & 30 \\
1.436 & 1.05 & Turquoise & 0.723 & 0.6276 & 520 & 450 & 30 \\
1.435 & 10.0 & White & 0.720 & 5.9646 & 520 & 450 & 30 \\
\hline
\end{tabular}

PE, polyethylene.

$M R T$ of fuid and of plastic particles distal to the reticulo-rumen $\left(M R T_{\text {Gut }}\right)$

Plastic particles (1000) with a length of $1 \mathrm{~mm}$ of each density and 200 plastic particles with a length of $10 \mathrm{~mm}$ of each density were mixed and placed in four gelatine capsules $(4 \mathrm{ml}$; WDT, Hannover). The experiment was carried out about 4 weeks after the determination of $\mathrm{MRT}_{\mathrm{GIT}}$. At 08.00 hours of day 1 capsules were administered manually through the reticulo-omasal orifice between the leaves of the omasum. A single dose of $3 \mathrm{~g}$ PEG dissolved in $15 \mathrm{ml}$ water was given into the omasum via a plastic tube. Total faecal output was collected at $3 \mathrm{~h}$ intervals on the 1 st day, $6 \mathrm{~h}$ intervals on the $2 \mathrm{nd}$ day and twice daily for the following $3 \mathrm{~d}$. After collection the samples were divided into a one-third (a) and a two-third (b) subsample. Subsample (a) was dried and analysed as described previously. Both 1 and $10 \mathrm{~mm}$ particles of each density were weighed. A $1 \mathrm{~g}$ subsample of the ground faeces was taken for PEG estimation. To obtain a suitable number of $10 \mathrm{~mm}$ particles in the whole faecal sample, subsample (b) was soaked in water for $4 \mathrm{~h}$. Then the slurry was poured into a sieve with a pore diameter of $1 \mathrm{~mm}$ (Retsch, Haan) and with a high-pressure water jet the $10 \mathrm{~mm}$ particles were separated and weighed for each density.

\section{Calculations}

Rumen fluid volume was calculated by dividing the amount of PEG added by its concentration at time zero using regression analysis. The MRT of fluid in the reticulorumen $\left(\mathrm{MRT}_{\mathrm{RR}}\right)$ was calculated as $\mathrm{MRT}_{\mathrm{RR}}=k^{-1}$. The proportion of marker leaving the compartment per hour $(k)$ can be calculated from the equation

$$
k=\left(\ln C_{0}-\ln C_{t}\right) \times t^{-1},
$$

where $C_{0}$ is the marker concentration at zero time calculated by regression analysis and $C_{t}$ is the marker concentration at sampling time $t$. The $\mathrm{MRT}_{G \mathrm{IT}}$ of fluid was calculated as $\mathrm{MRT}_{\mathrm{RK}}+\mathrm{MRT}_{\text {(int }}$.

The $\mathrm{MRT}_{\text {GIT }}$ of plastic particles and the $\mathrm{MRT}_{\text {Gut }}$ of fluid and plastic particles were calculated according to Thielemans et al. (1978):

$$
\text { MRT }=\left(\Sigma C_{t} \times t \times d t\right)\left(\Sigma C_{t} \times d t\right)^{-1},
$$

where $C_{t}$ is the marker concentration in the sample, $t$ is the time-interval after particle administration at which the sample was taken, and $d t$ is the faecal collection interval.

The $\mathrm{MRT}_{\mathrm{RR}}$ of plastic particles was calculated as $\mathrm{MRT}_{\mathrm{RR}}=\mathrm{MRT}_{\mathrm{GIT}}-\mathrm{MRT}_{\mathrm{Gut}}$.

The effects of particle length and particle density on MRT were evaluated by using a block analysis of variance with a blocking factor of sheep and the treatment factors of 


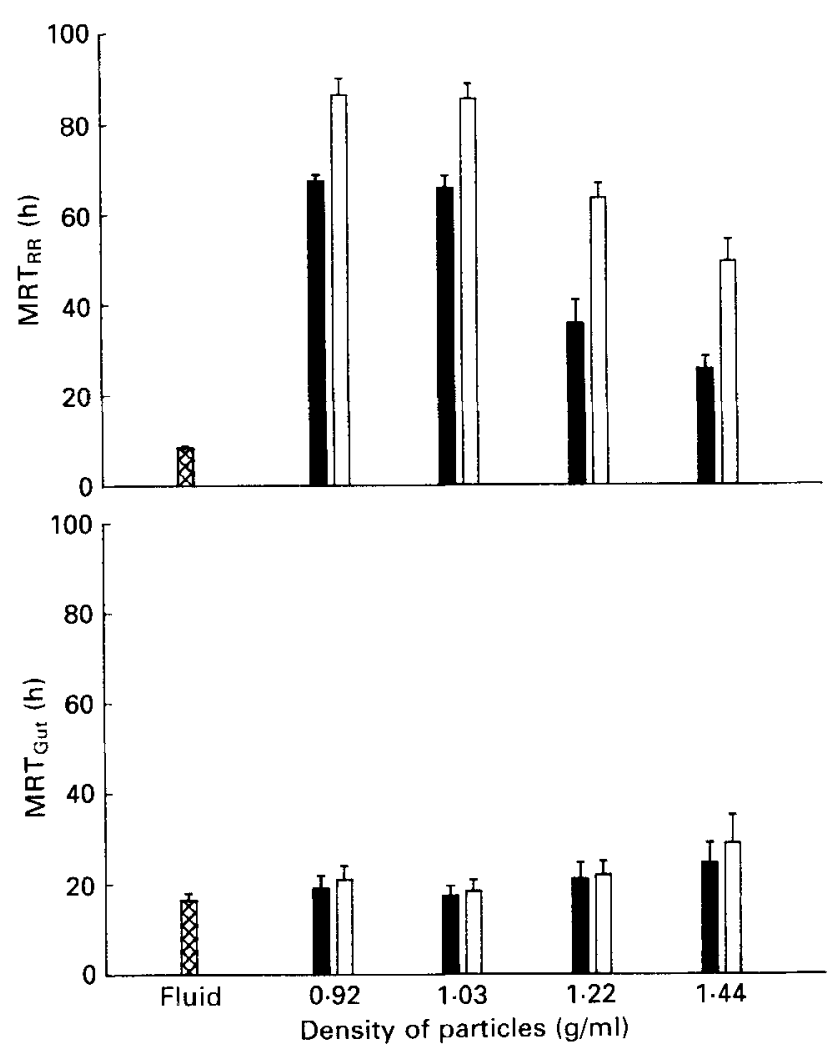

Fig. 1. Mean retention time of fluid $(\nabla)$ and of $1(\boldsymbol{O})$ and $10(\square) \mathrm{mm}$ long plastic particles of four different densities in the reticulo-rumen $\left(\mathrm{MRT}_{\mathrm{RH}}\right)$ and distal to the reticulo-rumen $\left(\mathrm{MRT}_{\mathrm{Gut}}\right)$ of sheep. Values are means with their standard errors, represented by vertical bars, for four sheep.

particle density and particle length (Winer, 1971). A multiple regression analysis with two dependent variables was applied to determine the quantitative contribution of particle density and particle size on $\mathrm{MRT}_{\mathrm{R} R}$.

Results are given as means and standard errors. Significance of differences between the MRT and the faecal recoveries of particles were tested using the Tukey-test for multiple mean comparison (Winer, 1971).

\section{RESULTS}

\section{Feed intake and rumen volume}

For both sets of the experiment, feed intake averaged 1869 (SE 45) g hay/d, i.e. 1699 (SE 41) g dry matter/d. Rumen fluid volume was $13 \cdot 2$ (SE 0.7) litres or 206 (SE 13) g/kg bodyweight for both sets of the experiment respectively.

$$
M R T_{n: t}
$$

Applying the analysis of variance a significant effect of particle density on $M_{R T} T_{k R}$ was found $(P<0.001$; Fig. 1). However, the multiple-mean-comparison test showed no significant difference in $\mathrm{MRT}_{\mathrm{RR}}$ between particles of similar size with densities of 0.92 and $1 \cdot 03 \mathrm{~g} / \mathrm{ml}$.

Particles $(1 \mathrm{~mm})$ with a low density $(0.92$ and $1.03 \mathrm{~g} / \mathrm{ml})$ were retained two to three times 
Table 2. Mean retention time in the total gastrointestinal tract $\left(M R T_{G I T}\right)$ of fluid and of plastic particles with different sizes and densities

(Mean values and standard errors for four sheep)

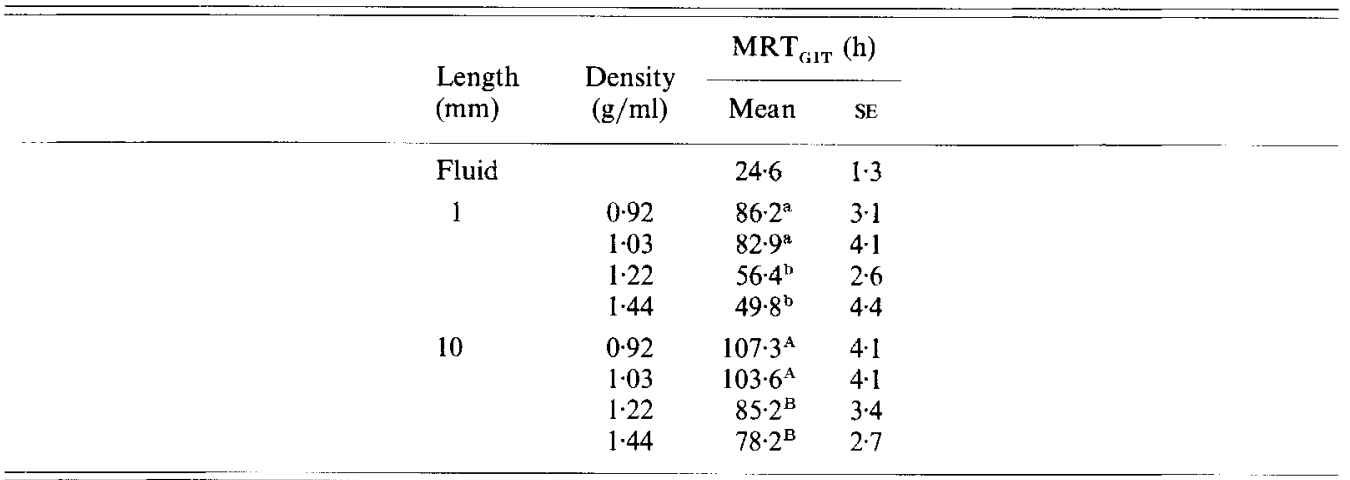

Means were compared between the different densities within each size; values with different superscript letters were significantly different $(P<0 \cdot 01)$; differences between 1 and $10 \mathrm{~mm}$ particles of each density were significantly different $(P<0.01)$.

longer than the heavier particles of the same length $(0.92 \mathrm{~g} / \mathrm{ml}: 67.3(\mathrm{SE} 1.4) \mathrm{h} ; 1.03 \mathrm{~g} / \mathrm{ml}$ : 65.7 (SE 2.8) h; $1.22 \mathrm{~g} / \mathrm{ml}: 35.5$ (SE 5.2) h; $1.44 \mathrm{~g} / \mathrm{ml}: 25.4$ (SE 2.9) h). The $\mathrm{MRT}_{\mathrm{RR}}$ of light particles was eight times longer and for small heavy particles three times longer than the $\mathrm{MRT}_{\mathrm{RR}}$ of fluid $(8 \cdot 3(\mathrm{SE} 0 \cdot 3) \mathrm{h})$.

Particles with a length of $10 \mathrm{~mm}$ were retained significantly longer $(P<0.001)$ in the reticulo-rumen than $1 \mathrm{~mm}$ particles. Most of the $10 \mathrm{~mm}$ particles were found comminuted in the faeces to a size of $0.5-4 \mathrm{~mm}$; the amount of unchewed $10 \mathrm{~mm}$ particles in the faeces was highest for particles with a density of $1.44 \mathrm{~g} / \mathrm{ml}(0.037$ of the administered particles $)$. The MRT $\mathrm{RR}_{\mathrm{R}}$ of particles with a length of $10 \mathrm{~mm}$ was on average $22.7 \mathrm{~h}$ longer than that of the $1 \mathrm{~mm}$ particles of the corresponding density; this difference between $\mathrm{MRT}_{\mathrm{RR}}$ of 1 and $10 \mathrm{~mm}$ particles was not influenced by particle density.

$$
M R T_{\text {Gut }}
$$

$\mathrm{MRT}_{\text {Gut }}$ was slightly $(P<0.05)$ influenced by particle density (Fig. 1); particle length did not have a marked effect on $\mathrm{MRT}_{\text {Gut }}$. Particles with a density of 0.92 and $1.03 \mathrm{~g} / \mathrm{ml}$ were retained for 19.9 (SE 2.0) h and 17.7 (SE 1.6) h respectively; these values were in the same range as $\mathrm{MRT}_{\text {(iu }}$ of fluid $(16 \cdot 3$ (SE 1.6) h). Heavy particles were retained longer than the light particles $(1.22 \mathrm{~g} / \mathrm{ml}: 21 \cdot 3$ (SE $2 \cdot 2) \mathrm{h} ; 1.44 \mathrm{~g} / \mathrm{ml}: 26 \cdot 6$ (SE $3 \cdot 7) \mathrm{h}$ ).

$$
M R T_{G I T}
$$

The negative correlation between particle density and MRT was somewhat less pronounced for $\mathrm{MRT}_{\mathrm{GI}}$ than for $\mathrm{MRT}_{\mathrm{RR}}$ due to the slight increase of $\mathrm{MRT}_{\mathrm{Gut}}$ with increasing density (Table 2).

\section{Faecal recovery}

When $\mathrm{MRT}_{\text {GIT }}$ was determined, faecal recoveries were significantly higher $(P<0.001)$ for $1 \mathrm{~mm}$ particles $(81.8$ (SE 2.0$) \%$ of the particles fed) than for the $10 \mathrm{~mm}$ particles $(67.6$ (SE $1.5) \%$ of the particles fed; Table 3 ). This may be explained by the greater comminution of large particles by chewing, leading to a higher loss during sieving of the subsamples. Particles with a higher density had significantly higher faecal recoveries $(P<0.001)$ than lighter particles due to their shorter MRT. 
Table 3. Faecal recoveries of plastic particles of different sizes and densities $(\%$ of total weight applied). For the estimation of the mean retention time $(M R T)$ in the gastrointestinal tract $\left(M R T_{G I T}\right)$, faeces were collected for $10 \mathrm{~d}$ after particles were fed; for the estimation of the $M R T$ in the gastrointestinal tract distal to the reticulo-rumen $\left(M R T_{G u t}\right)$, faeces were collected for $5 d$ after the administration of the particles into the omasum

(Mean values and standard errors for four sheep)

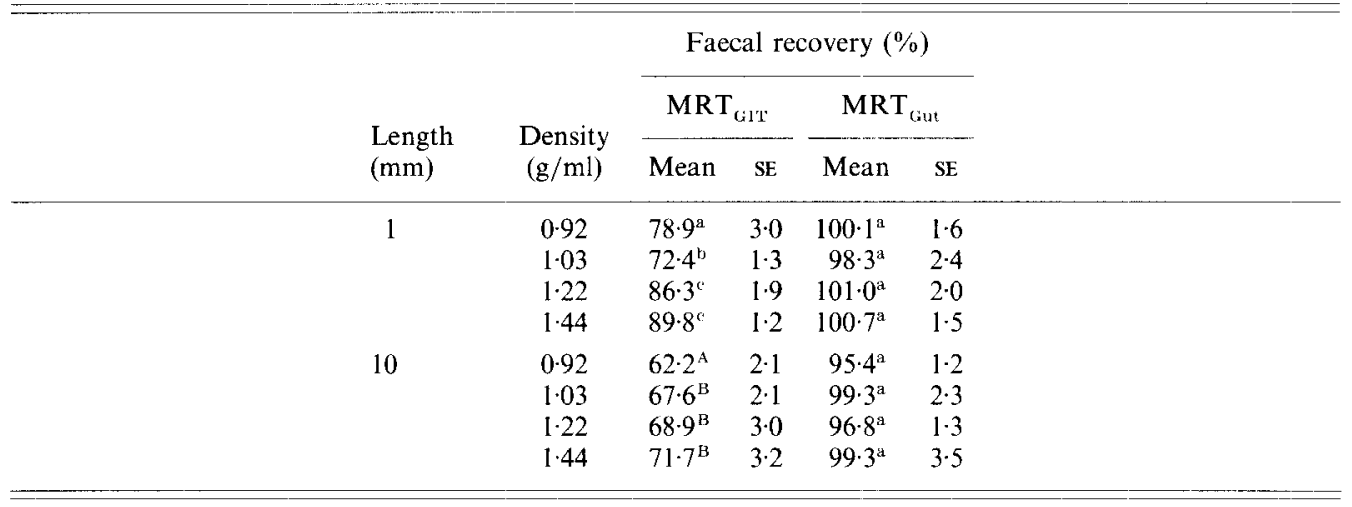

\footnotetext{
Means were compared between the different densities within each size; values with different superscript letters were significantly different $(P<0 \cdot 01)$; differences between 1 and $10 \mathrm{~mm}$ particles of each density were significantly different $(P<0 \cdot 01)$.
}

When MRT $_{\text {Gut }}$ was determined, faecal recoveries were independent of particle length and density and averaged $98 \cdot 8$ (SE $0 \cdot 7) \%$.

\section{DISCUSSION \\ Density of particles}

Large feed particles entering the rumen mostly have a density below $1.0 \mathrm{~g} / \mathrm{ml}$ based on an air-filled interior (Evans et al. 1973; Van Soest, 1975; Sutherland, 1988). Particle size decreases during the digestion process due to rumination and microbial breakdown; particle density increases due to hydration, ion-exchange and destruction of cellular space, and values up to $1.4 \mathrm{~g} / \mathrm{ml}$ have been measured (Hooper \& Welch, 1985). To study the influence of density on MRT it was essential in our experiment to use inert plastic particles whose density did not change in the forestomach.

Our findings clearly underline the marked influence of the density of particles on $\mathrm{MRT}_{\mathrm{RR}}$. Particles of length $1 \mathrm{~mm}$ with a density of $1.44 \mathrm{~g} / \mathrm{ml}$ left the reticulo-rumen 2.6 times faster than those of densities of 0.92 and $1.03 \mathrm{~g} / \mathrm{ml}$ (Fig. 1). This is in agreement with studies in cows (desBordes \& Welch, 1984; Ehle, 1984) and sheep (Lindberg, 1985; Katoh et al. 1988) where the highest passage rates were found for particles with a density of $1.38-1.5 \mathrm{~g} / \mathrm{ml}$. Particles with very high densities of 1.77 and $2.15 \mathrm{~g} / \mathrm{ml}$, on the other hand, were retained longer. However, feed particles normally do not reach a density higher than $1.5 \mathrm{~g} / \mathrm{ml}$ (Evans et al. 1973).

\section{Particle size}

Particles $10 \mathrm{~mm}$ in length of all densities were retained in the reticulo-rumen of our sheep $19 \cdot 1-27.9 \mathrm{~h}$ longer than the $1 \mathrm{~mm}$ long particles. Most of these large particles were found comminuted to a size of $0.5-4 \mathrm{~mm}$ in faeces. Although breakdown of large particles is obviously essential for a high outflow rate, rumination alone does not guarantee a high 
passage rate. Ruminated particles with a low density may be small enough for passage into the omasum, but they are retained considerably longer in the reticulo-rumen than the heavier particles. Likewise, $\mathrm{MRT}_{\mathrm{RR}}$ of heavy particles with a length of $10 \mathrm{~mm}$ was markedly shorter than that of the $1 \mathrm{~mm}$ long particles with low densities, although the larger particles had to be ruminated before outflow from the reticulo-rumen.

\section{Quantitative contribution of particle density and length to $M R T_{R R}$}

From our findings it was possible to estimate by multiple-regression analysis the quantitative contribution of particle length and density to MRT. The first condition for the calculation is a linear decline of $\mathrm{MRT}_{\mathrm{KR}}$ with increasing particle density between 0.92 and $1.44 \mathrm{~g} / \mathrm{ml}$. Such a linear relation may be assumed from our findings (Fig. 1); this was also shown by Ehle (1984) and Lindberg (1985). The second assumption is an exponentially decreasing probability of passage of particles from the reticulo-rumen with increasing particle length. Such a relation was shown for feed particles by Welch \& Smith (1978) and Poppi et al. (1980) and, in an additional study, for plastic particles. In these experiments, the reticulo-rumen was emptied and filled with buffer solution. Particles $(1,5,10,20 \mathrm{~mm}$ with a density of $1.03 \mathrm{~g} / \mathrm{ml}$ ) were given into the ventral sac of the rumen and sedimentation was inhibited largely by bubbling the buffer solution. Particles could leave the reticulorumen only at their original size because the sheep did not ruminate during the $4 \mathrm{~h}$ experiment. In fact, a negative exponential relation between outflow from the reticulorumen and particle size had been found (Kaske, 1987).

Regression analysis using the values of $\mathrm{MRT}_{\mathrm{RR}}$ (Fig. 1) showed that $87 \%$ of the total variation of $\mathrm{MRT}_{\mathrm{RR}}$ could be explained by the factors particle density and particle size. Other factors obviously had no major effect in our experiment. Particle density accounted for $59 \%$ of the total variation of $\mathrm{MRT}_{\mathrm{RR}}$; particle size determined $28 \%$ of the variation of $\mathrm{MRT}_{\mathrm{RR}}$.

The application of our results for feed particles is justifiable only if the breakdown rate of our plastic particles is comparable to that of feed particles. Using the findings of Ulyatt et al. (1986) we estimated a breakdown rate for feed particles in the range of $0.07 / \mathrm{h}$. The breakdown rate of our plastic particles seems to be comparable with this value. Approximately $24 \mathrm{~h}$ after feeding, the probability for passage of particles with a length of $10 \mathrm{~mm}$ was the same as that for particles with a size of $1 \mathrm{~mm}$. In further experiments the plastic particles were ruminated at a rate of $0.073 / \mathrm{h}$ (M. Kaske, unpublished results).

\section{$M R T_{R R}$ of feed particles with changing density}

In contrast to our experiment the density of feed particles changes during the digestion process. However, little is known about the rate at which the density of feed particles increases during their stay in the reticulo-rumen. Hooper \& Welch (1985) and Nocek \& Kohn (1987) placed forage particles in nylon bags in the rumen. The density of feed particles increased rapidly within $1 \mathrm{~h}$ after introduction of particles into the rumen from $0.9 \mathrm{~g} / \mathrm{ml}$ up to approximately $1.1 \mathrm{~g} / \mathrm{ml}$. During the following $28 \mathrm{~h}$ a further relatively slow increase in particle density was observed. Highest values of about $1.4 \mathrm{~g} / \mathrm{ml}$ were reached after an incubation period of 52-76 h. Small particles increased in density faster than large particles, and the rate of density change seemed to be different for different feeds; e.g. legume particles changed their density faster than grass particles.

\section{$M R T_{G u t}$ of particles of different size and density}

While particle size had no clear influence on $\mathrm{MRT}_{\mathrm{Gut}}$ in our experiment, particles with a density of $1.44 \mathrm{~g} / \mathrm{ml}$ were retained somewhat longer than particles with a density of $1.03 \mathrm{~g} / \mathrm{ml}$. These results contrast with the generally accepted concept of similar passage rates 
for particles and fluid in the gut of ruminants. Nevertheless, the absolute difference between MRT $_{\text {Gut }}$ of heavy and light particles $(26.6 \mathrm{~h}$ and $17.7 \mathrm{~h}$ respectively) was small compared with the marked differences in $\mathrm{MRT}_{\mathrm{RR}}$. Furthermore the tendency for a longer retention of heavy particles differed considerably between the four animals. However, Campling \& Freer (1962) found a stronger influence of particle density on $\mathrm{MRT}_{\text {(iut }}$ in cows; $\mathrm{MRT}_{\text {Gut }}$ of particles with a density of $1.21 \mathrm{~g} / \mathrm{ml}(52 \mathrm{~h})$ was $78.4 \%$ longer than the retention time of particles with a density of $1.02 \mathrm{~g} / \mathrm{ml}(29 \mathrm{~h})$.

\section{Conclusions}

The passage of particles into the omasum seems to be primarily limited by the velocity of density increase of the particles in the reticulo-rumen. Rumination diminishes particle size rapidly. A high particle density considerably increases the probability of outflow. The preferential passage of the small, heavy particles into the omasum seems to be physiologically sensible, because these particles are mostly sufficiently digested. The longer retention of the light particles, on the other hand, is a prerequisite for efficient digestion of the cellulose in the feed.

The authors gratefully acknowledge the assistance and advice of Mrs G. Becker and Dr M. Lechner-Doll. Studies were supported by a research grant from the Deutsche Forschungsgemeinschaft (DFG En 65/11).

\section{REFERENCES}

Campling, R. C. \& Freer, M. (1962). The effect of specific gravity and size on the mean retention time of inert particles in the alimentary tract of the cow. British Journal of Nutrition 16, 507-518.

desBordes, C. K. \& Welch, J. G. (1984). Influence of specific gravity on rumination and passage of indigestible particles. Journal of Animal Science 59, 470-475.

Durkwa, L. (1983). Length and specific gravity of particles passed from the rumen and changes in ingesta specific gravity. PhD Thesis, University of Vermont, Burlington.

Ehle, F. R. (1984). Influence of feed particle density on particulate passage from the rumen of Holstein cows. Journal of Dairy Science 67, 693-697.

Ehle, F. R. \& Stern, M. D. (1986). Influence of particle size and density on particulate passage through alimentary tract of Holstein heifers. Journal of Dairy Science 69, 564-568.

Evans, E. W., Pearce, G. R., Burnett, J. \& Pillinger, S. L. (1973). Changes in some physical characteristics of the digesta in the reticulorumen of cows fed once daily. British Journal of Nutrition 29, 357-376.

Hooper, A. P., Palmer, R. H. \& Welch, J. G. (1984). A method to determine specific gravity of rumen digesta or of forage samples incubated in nylon bags. Techniques in Particle Size Analysis of Feed and Digesta in Ruminants. Canadian Society of Animal Science, Occasional Publication no. 1, Edmonton, Canada, pp. 190-191.

Hooper, A. P. \& Welch, J. G. (1985). Effects of particle size and forage composition on functional specific gravity. Journal of Dairy Science 68, 1181-1188.

Hydén, J. E. (1955). A turbidimetric method of the determination of higher polyethylene glycols in biological material. Kungliga Lantbrukshögskolans Annaler 22, 139-145.

Kaske, M. (1987). Die Retention von Partikeln unterschiedlicher Dichte und Größe im Retikulorumen von Schafen. Inaugural-Dissertation, Hannover.

Katoh, K., Sato, F., Yamazaki, A., Sasaki, Y. \& Tsuda, T. (1988). Passage of indigestible particles of various specific gravities in sheep and goats. British Journal of Nutrition 60, 683-687.

King, K. W. \& Moore, W. E. C. (1957). Density and size as factors affecting passage rate of ingesta in the bovine and human digestive tract. Journal of Dairy Science 40, 528-536.

Lindberg, J. E. (1985). Retention time of chromium-labelled feed particles and of water in the gut of sheep given hay and concentrate at maintenance. British Journal of Nutrition 53, 559-567.

Martz, F. A. \& Belyea, R. L. (1986). Role of particle size and forage quality in digestion and passage by cattlc and sheep. Journal of Dairy Science 69, 1996-2008.

Nehring, K. (1960). Agrikulturchemische Untersuchungsmethoden. (Agricultural-chemical examination methods.), 3rd ed. Hamburg/Berlin: P. Parey.

Nocek, J. E. \& Kohn, R. A. (1987). Initial particle form and size on change in functional specific gravity of alfalfa and timothy hay. Journal of Dairy Science $\mathbf{7 0}, 1850-1863$.

Poppi, D. P., Norton, B. W., Minson, D. J. \& Hendricksen, R. E. (1980). The validity of the critical size theory for particles leaving the rumen. Journal of Agricultural Science 94, 275--280. 
Reid, C. S. W., Ulyatt, M. J. \& Monro, J. A. (1977). The physical breakdown of feed during digestion in the rumen. Proceedings of the New Zealand Society of Animal Production 37, 173-175.

Sutherland, T. (1988). Particle separation in the forestomachs of sheep. In Comparative Aspects of Physiology of Digestion in Ruminants, pp. 43-73 [A. Dobson and M. Dobson, editors]. New York: Cornell University Press.

Thielemans, M. F., Francois, E., Bordart, C. \& Thewis, A. (1978). Mesure du transit gastrointestinal chez le porc a l'aide des radiolanthanides. Comparaison avec le mouton. (Gastrointestinal transit in the pig: measurement using radioactive lanthanides. Comparison with sheep.) Annales de Biologie Animale, Biochimie, Biophysique 18 , 237-247.

Troelsen, J. E. \& Campbell, J. B. (1968). Voluntary consumption of forage by sheep and its relation to the size and shape of particles in the digestive tract. Animal Production 10, 289-298.

Ulyatt, M. J. (1983). Plant fibre and regulation of digestion in the ruminant. In Fibre in Human and Animal Nutrition. pp. 103-107 [G. Wallace and L. Bell, editors]. Wellington, New Zealand: The Royal Society of New Zealand.

Ulyatt, M. J., Dellow, D. W., John, A., Reid, C. S. W. \& Waghorn, G. C. (1986). Contribution of chewing during eating and rumination to the clearance of digesta from the ruminoreticulum. In Control of Digestion and Metabolism in Ruminants, pp. 498-515 [L. P. Milligan, W. L. Grovum and A. Dobson, editors]. New Jersey: Prentice-Hall.

Van Soest, P. J. (1975). Physico-chemical aspects of fibre digestion. In Digestion and Metabolism in the Ruminant, pp. 351-365 [I. W. McDonald and A. C. I. Warner, editors]. Armidale, Australia: University of New England Publishing Unit.

Welch, J. G. (1982). Rumination, particle size and passage from the rumen. Journal of Animal Science 54, 885-894. Welch, J. G. \& Smith, A. M. (1978). Particle sizes passed from the rumen. Journal of Animal Science 46, $309-312$. Wincr, B. J. (1971). Statistical Principles in Experimental Design, 2nd. ed. Tokyo: Koseido Printing Co. 